\title{
Field Experimental Study on Electrical Power Generation Using AC Single-Phase Permanent Magnet Generator
}

\author{
I Made Wiwit Kastawan ${ }^{1 *}$, Erwin Yusuf ${ }^{2}$, Rusmana Rusmana ${ }^{2}$, Krisna Krisna ${ }^{1}$ \\ ${ }^{1}$ Diplome-III Program Study of Energy Conversion Engineering, Department of Energy Conversion Engineering, \\ Politeknik Negeri Bandung \\ ${ }^{2}$ Diplome-IV Program Study of Electrical Power Plant Technology, Department of Energy Conversion Engineering, \\ Politeknik Negeri Bandung \\ *Corresponding author. Email: wiwit.kastawan@polban.ac.id
}

\begin{abstract}
A single-phase ac permanent magnet generator has been constructed by modifying a squirrel cage single-phase ac induction motor by embedding permanent magnet poles in the rotor and rewinding the armature stator windings. This single-phase ac permanent magnet generator is then used to generate electricity from small river with low speed of water flow by coupling it with a low head hydro turbine. The low head hydro turbine is installed in two different configurations i.e., tilted and non-tilted or parallel to the flow of the river, to increase rotation speed. A water guide vane is also used for the same purpose. Field experimental test results show that the single-phase ac permanent magnet generator able to produce highest output voltage at $32 \mathrm{~V}$ on rotation speed of $260 \mathrm{rpm}$.
\end{abstract}

Keywords: electrical power, hydro, low-head turbine, permanent magnet generator, small river.

\section{INTRODUCTION}

Electric motor is a kind of electric machine used to convert electrical energy to rotating mechanical energy. Among many kinds of electric motor, ac induction motor is the most widely used in residential, industrial, and commercial applications [1]. Ac induction motors are easier to find in market with relatively lower price than other kinds of electric motor. At the other side, generator is an electric machine used to convert rotating mechanical energy to electrical energy. Generator of various types and capacities are used in many kinds of electrical power generation system. In a very small hydro power generation system, with capacity of fraction of kilowatt, single-phase ac permanent magnet generator is commonly used. A very small hydro power generation system is generally constructed in a small river with low speed of water flow [2], [3]. Thus, requires energy conversion engines able to work on low rotation speed. At the first stage, a low-speed hydro turbine is used to convert hydro potential energy of the small river to shaft rotating mechanical energy. At the second stage, a lowspeed generator converts further the shaft rotating mechanical energy to electrical energy.
Low head hydro turbine is a kind of low-speed hydro turbine. The crossflow horizontal shaft is a type of low head hydro turbine frequently used in a small hydro power generation system. It has number of blades that directly contact and move along with stream of the small river. All blades are supported by a wheel firmly attached to the shaft of turbine. The wheel then delivers motion of blades to the shaft of turbine. The shaft of turbine is supported by bearings placed at its both sides. The bearing house is firmly attached on concrete floors constructed at both sides of the small river. [4]

Many kinds of ac permanent magnet generator have been developed. First one is the axial flux permanent magnet (AFPM) generator. AFPM generator has a simple construction. It is basically consisted of rotor and stator discs [5]. AFPM generator is frequently used in small low-speed electrical power generation system such as wind, pico-hydro and micro- hydro [6-10]. Second one is the conventional radial flux ac permanent magnet generator with cylindrical shaped rotor and stator. This generator can be constructed by simply modifying rotor and stator parts of a squirrel cage single-phase ac induction motor [11]. Modifying a squirrel cage single- 
phase ac induction motor to a single-phase ac permanent magnet generator for application of electrical power generation of small river may give the following advantages [13],[14]:

a) Single-phase ac permanent magnet generator requires no external dc excitation source. Thus, it is very suitable for harnessing hydro potential energy of small rivers in remote area, an area not yet connected to existing electrical grid.

b) Ac induction motor, particularly the squirrel cage single-phase one, is widely used for many applications in residential, industrial, and commercial sector. Hence, modifying a used squirrel cage singlephase ac induction motor to single-phase ac permanent magnet generator is more economical and help solving motor disposal problem.

Previously, in earlier research, a squirrel cage singlephase ac induction motor has been modified to a singlephase ac permanent magnet generator. The generator has 8 permanent magnet poles and 4 stator windings. Each stator winding is consisted of 150 conductor turns. Result of no-load laboratory test shows that output voltage is $110 \mathrm{~V}$ when generator rotates close to its nominal speed $750 \mathrm{rpm}$. Result of on-load laboratory test shows that voltage drops and efficiencies of the generator vary from $4.5 \%$ to $29.1 \%$ and $32.6 \%$ to $67.5 \%$ respectively [11]. For the next step, this single-phase ac permanent magnet generator is going to be applied in a small hydro power generation system. The purpose is to analyze its performance in a relevant environment application.

This paper describes using of a single-phase ac permanent magnet generator to convert hydro potential energy of a small river to electrical energy. The singlephase ac permanent magnet generator is a product of modification of a squirrel cage single-phase ac induction motor done in earlier research [11]. The single-phase ac permanent magnet generator is going to be coupled with a low head hydro turbine. The low head hydro turbine is also a product of design and construction already done in another earlier research. This low head hydro turbine is designed to work on a shallow river (about $2 \mathrm{~m}$ deep) with about $1 \mathrm{~m} / \mathrm{s}$ to $2 \mathrm{~m} / \mathrm{s}$ speed of water flow. The turbine is $500 \mathrm{~mm}$ wide with diameter of $750 \mathrm{~mm}$. It has 12 blades. Tilt angle of each blade is $30^{\circ}$ and distance between two adjacent blades is equal to $195 \mathrm{~mm}[12$ paper di AFC Korea]. Therefore, main steps remain to be done in this research are selecting a small river suitable for field experimental test purpose, designing and constructing a mechanic power transmission system for the low head hydro turbine and the single-phase ac permanent magnet generator, and installing small hydro power generation unit developed in a selected river that is then followed by running the test.

\section{RESEARCH METHODS}

As explained above, this paper describes the three main research steps taken in regard to use of a singlephase ac permanent magnet generator to convert hydro potential energy of a small river to electrical energy. All those steps are described in detail in the following subsections.

\subsection{Selecting Field Experimental Test Location}

A small river that becomes a part of Bengkok Dago Hydroelectric Power Plant in Bandung has been chosen as the field experimental test location based on two main considerations i.e., higher debit of water and easiness of access and mobilization for person and experimental equipment. Width of the selected river is $1.5 \mathrm{~m}$ with depth varies from $1 \mathrm{~m}$ to $1.5 \mathrm{~m}$ depending on weather condition and electricity production of the Bengkok Dago Hydroelectric Power Plant. The speed of water flow is measured manually by floating method. A floating object is tied in a $6 \mathrm{~m}$ long rope. Then, time of the object when moving on the water along $6 \mathrm{~m}$ long rope is taken to calculate the speed of water flow. When the speed of water is obtained, the hydro energy potential of the small river or input energy of the low head hydro turbine can be calculated as [15]:

$\mathrm{P}_{\text {hydro }}=\frac{1}{2} \rho \mathrm{v}^{3} \mathrm{~A}$

In which $\mathrm{P}_{\text {hydro }}, \rho, \mathrm{v}$ and $\mathrm{A}$ denote hydro energy potential of the small river that is equal to input energy of the low head hydro turbine $(\mathrm{W})$, density of water $\left(\mathrm{kg} / \mathrm{m}^{3}\right)$, speed of water flow $(\mathrm{m} / \mathrm{s})$ and cross-sectional area of the water flow $\left(\mathrm{m}^{2}\right)$.

Considering that the river is $1.5 \mathrm{~m}$ wide while the low head hydro turbine is only $0.5 \mathrm{~m}$ wide then a water guide vane construction is needed. The water guide vane will direct flow of the river to the low head hydro turbine. It will increase speed of water flow as well as rotation speed and input energy of the low head hydro turbine. The shaft rotation speed of the low head hydro turbine will determine the design of mechanic power transmission system. Higher rotation speed requires pulleys with smaller diameter. Further, the smaller the diameter of pulleys, the shorter is the belt needed to connect them.

\subsection{Designing the Pulley}

A pulley system has been selected as mechanic power transmission system between the low head hydro turbine and the single-phase ac permanent magnet generator. The design of pulley is determined by turbine rotation measurements data. The turbine rotation will be compared with the rated generator rotation according to this formula: 


$$
\frac{\mathrm{N}_{2}}{\mathrm{~N}_{1}}=\frac{\mathrm{d}_{1}}{\mathrm{~d}_{2}}
$$

with $\mathrm{N}$ refers to rotation speed (rpm) and $\mathrm{d}$ refers to diameter of pulleys.

Diameter ratio in equation (2) could be met by several pulley transmission stages such as one-stage, two-stage and so on. Considering frame dimension of the low head hydro turbine, using pulley transmission stage higher than two could not be applied. Two-stage pulley transmission clearly requires more pulley than one-stage pulley transmission. However, diameter of each pulley of two-stage pulley transmission will be shorter than diameter of each pulley of one-stage pulley transmission.

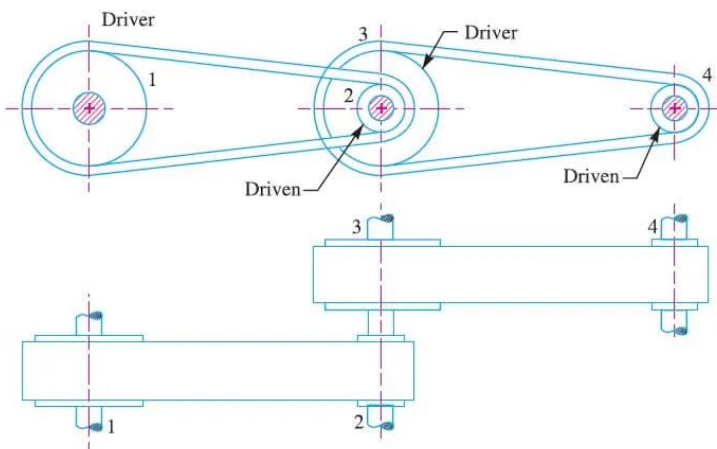

Figure 1 Two-stage pulley transmission

The pulleys need to be connected by belts. In this research, flat belt type is used. Length of the belt is determined by diameter of pulleys to be connected, contact angle between belt and pulley, and distance between two pulley's center points.

\subsection{Installing the Small Hydro Power Generation Unit and Conducting Field Experimental Test}

After the low head hydro turbine and the single-phase ac permanent magnet generator are coupled through a pulley and belt power transmission system (forming a unit may called as small hydro power generation unit) then the next step is installing it in a selected small river continued by running field experimental test. The test is aimed to get power generation capability of the small hydro power generation unit developed.

\section{RESULTS AND DISCUSSION}

\subsection{Construction of Water Guide Vane}

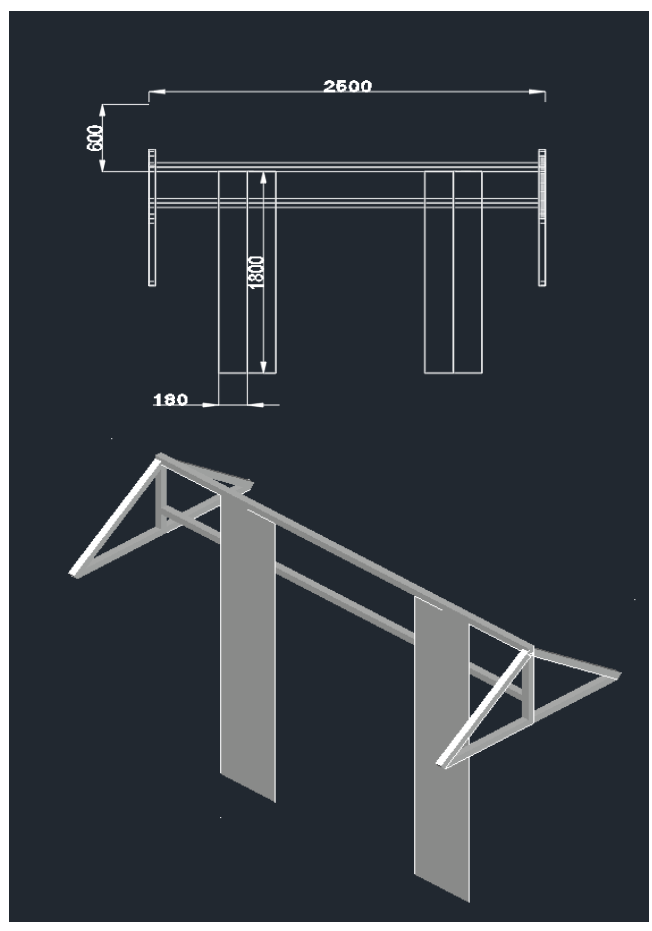

Figure 2 The water guide vane

It has been explained previously that a water guide vane is necessary to be constructed because width of the selected small river is $1.5 \mathrm{~m}$ while width of the low head hydro turbine is only $0.5 \mathrm{~m}$. Figure 2 above shows design of the water guide vane. In general, this kind of water guide vane construction is relatively simple and strong enough to withstand the water pressure. This water guide vane is installed at $0.5 \mathrm{~m}$ depth considering the optimum depth of low head hydro that is about $0.15 \mathrm{~m}$ to $0.5 \mathrm{~m}$. Main disadvantage of this water guide vane design is the directed water flow will be very short. Therefore, the low head hydro turbine has to be installed very close to this water guide vane, about $0.3 \mathrm{~m}$ to $0.5 \mathrm{~m}$.

\subsection{Measuring the Hydro Power Potential}

First measurement taken in the selected small river is measurement of speed of the water flow. Having data of speed of the water flow then debit $(\mathrm{Q})$ can be calculated using the following equation [15]:

$\dot{\mathrm{Q}}=\mathrm{Av}$

In which $\mathrm{v}$ and $\mathrm{A}$ denote speed of water flow $(\mathrm{m} / \mathrm{s})$ and cross-sectional area of the water flow $\left(\mathrm{m}^{2}\right)$ respectively. Because the small river is about $1.5 \mathrm{~m}$ wide, and the water deep is taken as $0.5 \mathrm{~m}$ then the crosssectional area of water flow will be equal to $0.75 \mathrm{~m}^{2}$. Table 1 below shows the measurement data of speed and 
calculated debit of the water flow for the small river has been selected for field experimental study.

Table 1. Speed and debit of water flow of selected small river

\begin{tabular}{|c|c|}
\hline $\begin{array}{c}\text { Speed of the water flow } \\
(\mathrm{m} / \mathrm{s})\end{array}$ & $\begin{array}{c}\text { Debit of the water flow } \\
\left(\mathrm{m}^{3} / \mathrm{s}\right)\end{array}$ \\
\hline 1.304 & 0.9783 \\
\hline 1.293 & 0.9698 \\
\hline 1.290 & 0.9677 \\
\hline 1.261 & 0.9454 \\
\hline 1.330 & 0.9978 \\
\hline
\end{tabular}

Next, using the speed of water flow data given in Table 1, the hydro power potential of the small river may be calculated using equation (1). Results of the calculation is listed in Table 2 below. When calculating this hydro energy potential, the cross-sectional area of water flow is taken as $0.075 \mathrm{~m} 2$, considering that the water guide vane has been applied and deep of water flow is taken as $0.15 \mathrm{~m}$ (optimum depth of the low head hydro turbine). The average of hydro power potential is 81.65 Watt.

Table 2. Hydro power potential

\begin{tabular}{|c|c|c|}
\hline $\begin{array}{c}\text { Speed of the } \\
\text { water flow }(\mathrm{m} / \mathrm{s})\end{array}$ & $\begin{array}{c}\text { Cross-sectional area } \\
\text { of the water flow }\left(\mathrm{m}^{2}\right)\end{array}$ & $\begin{array}{c}\text { Hydro power } \\
\text { potential }(\mathrm{W})\end{array}$ \\
\hline 1.304 & 0.0750 & 83.22 \\
\hline 1.293 & 0.0750 & 81.08 \\
\hline 1.290 & 0.0750 & 80.56 \\
\hline 1.261 & 0.0750 & 75.10 \\
\hline 1.330 & 0.0750 & 88.30 \\
\hline
\end{tabular}

\subsection{Measuring the Rotation Speed of Low Head Hydro Turbine}

Rotation speed measurement of the low head hydro turbine is done by varying the depth when it installed in the selected small river. The aim is to find its highest rotation speed. The measured rotation speed will be used as reference for design of pulley transmission system for coupling of low head hydro turbine and single-phase ac permanent magnet generator. Table 3 below shows result of measurement of rotation speed of low head hydro turbine. The average rotation speeds are $61.4 \mathrm{rpm}, 66.24$ rpm, and $59.26 \mathrm{rpm}$ for depth of low head hydro turbine installation of $0.13 \mathrm{~m}, 0.15 \mathrm{~m}$ and $0.20 \mathrm{~m}$ respectively. The highest speed rotation is achieved when the low head hydro turbine is installed at $0.15 \mathrm{~m}$ deep in the selected river.
Table 3. Rotation speed of the low head hydro turbine

\begin{tabular}{|c|c|}
\hline $\begin{array}{c}\text { Depth of installation of low } \\
\text { head hydro turbine }(\mathrm{m})\end{array}$ & $\begin{array}{c}\text { Rotation speed of the low } \\
\text { head hydro turbine }(\mathrm{rpm})\end{array}$ \\
\hline \multirow{4}{*}{0.13} & 59.8 \\
\cline { 2 - 2 } & 60.8 \\
\cline { 2 - 2 } & 63.4 \\
\cline { 2 - 2 } & 59.9 \\
\hline \multirow{4}{*}{0.15} & 63.0 \\
\hline \multirow{5}{*}{} & 65.9 \\
\hline \multirow{4}{*}{0.20} & 69.7 \\
\hline & 63.5 \\
\hline & 64.9 \\
\hline \multirow{5}{*}{} & 67.2 \\
\hline & 53.7 \\
\hline & 58.0 \\
\hline & 61.8 \\
\hline
\end{tabular}

\subsection{Pulley Design}

Size of the pulley is determined according to equation (2). The single-phase ac permanent magnet generator is designed to rotate at $750 \mathrm{rpm}$. This is the nominal rotation speed of the generator. Meanwhile, the rotation speed of the low head hydro turbine is taken as $66.24 \mathrm{rpm}$, the highest average rotation speed. Therefore, substituting these values to equation (2) yield ratio of pulley diameter as follows:

$\frac{d_{1}}{d_{2}}=\frac{1}{12.3}$

For practical purpose, the pulley diameter ratio above is rounded to $1: 15$. Size of the shaft of single-phase ac permanent magnet generator is known to be $0.02 \mathrm{~m}$. Thus, size of its pulley should be larger than $0.02 \mathrm{~m}$. Supposed that one-stage pulley transmission is applied then size of the low head hydro turbine pulley will be 15 times larger. In order to reduce size of the low head hydro turbine pulley, a two-stage pulley transmission is preferred. Ratio of single-phase ac permanent magnet generator pulley and transfer pulley is 1:3 while ratio of transfer pulley and low head hydro turbine pulley is 1:5. Figure 3 below shows the design of two-stage pulley transmission used to couple the single-phase ac permanent magnet generator and the low head hydro turbine. 


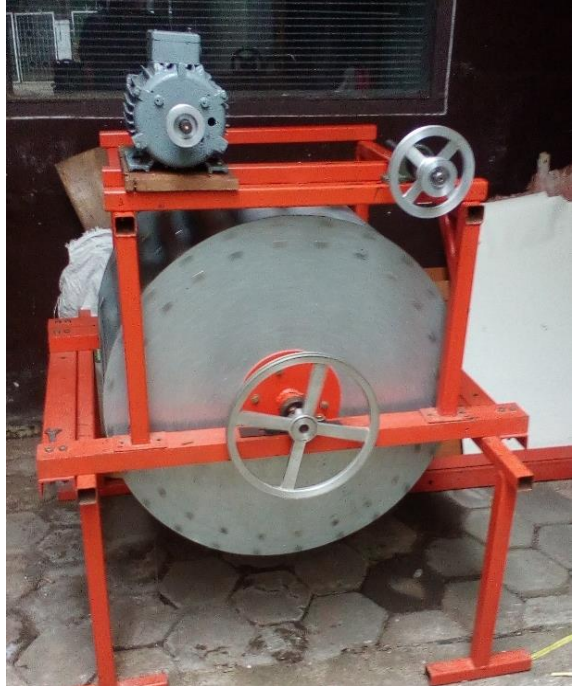

Figure 3 The two-stage pulley transmission for coupling of single-phase ac permanent magnet generator and low head hydro turbine.

\subsection{Field Experimental Test}

After successfully coupling the single-phase ac permanent magnet generator and low head hydro turbine to form a small hydro power generation unit, the next step then is running field experimental test. The small hydro power generation unit is installed in a location at the selected small river where water guide vane has been constructed before. Unfortunately, due to dry season, speed and debit of water flow available could not meet the demand for on-load field experimental test. Only the no-load field experimental test could be conducted. Table 4 below shows the results of the no-load field experimental test. It is shown that installing the low head hydro turbine in tilted position results in higher rotation speed which eventually increase the output voltage generated. Further, Table 5 gives data of the no-load test of the single-phase ac permanent magnet generator according to design/calculation and laboratory test [11]. Comparing data in Table 4 and Table 5, one can see that no-load voltage generated according to field experimental test confirm those according to design/calculation and laboratory test. For further analysis, field experimental test for on-load condition needs to be conducted to get complete performance i.e., voltage drop, and efficiency characteristic of the small hydro power generation unit developed.
Table 4. No-load Voltage Generation Capability of the Small Hydro Power Generation Unit Developed

\begin{tabular}{|c|c|c|}
\hline $\begin{array}{c}\text { Rotation speed of } \\
\text { the single-phase ac } \\
\text { permanent magnet } \\
\text { generator (rpm) }\end{array}$ & $\begin{array}{c}\text { Output voltage } \\
\text { generated }(\mathrm{V})\end{array}$ & $\begin{array}{c}\text { Setting of } \\
\text { the low } \\
\text { head hydro } \\
\text { turbine }\end{array}$ \\
\hline 100 & 13.5 & \multirow{2}{*}{ Non-tilted } \\
\hline 112 & 16.0 & \\
\hline 125 & 17.0 & \multirow{2}{*}{ Tilted } \\
\hline 128 & 18.0 & \\
\hline 246 & 29.0 & \\
\hline 246 & 30.0 & 31.0 \\
\hline 260 & 32.0 &
\end{tabular}

Table 5. No-load Voltage Generation Capability of the Single-Phase AC Permanent Magnet Generator [11].

\begin{tabular}{|c|c|c|}
\hline \multirow{2}{*}{$\begin{array}{c}\text { Rotation speed of } \\
\text { the single-phase ac } \\
\text { permanent magnet } \\
\text { generator (rpm) }\end{array}$} & $\begin{array}{c}\text { Output voltage (V) } \\
\text { Calculated/ } \\
\text { design }\end{array}$ & $\begin{array}{c}\text { Laboratory } \\
\text { test }\end{array}$ \\
\hline 75 & 11.3 & n.a. \\
\hline 113 & n.a. & 12.0 \\
\hline 150 & 22.6 & n.a. \\
\hline 152 & n.a. & 18.0 \\
\hline 198 & n.a. & 24.0 \\
\hline 225 & 33.9 & n.a. \\
\hline 258 & n.a. & 31.5 \\
\hline 308 & n.a. & 39.0 \\
\hline
\end{tabular}

n.a. = not available

\section{CONCLUSIONS}

1. A mechanical coupling between low head hydro turbine and single-phase ac permanent magnet generator by two-stage pulley transmission has been successfully done.

2. Field experimental test shows that on no-load condition the generator able to generate output voltage of around $31-32 \mathrm{~V}$ and $29-30 \mathrm{~V}$ on shaft rotation speed of $260 \mathrm{rpm}$ and $246 \mathrm{rpm}$ respectively. These output voltage figures conform to laboratory test results as well as the output voltage according to design/calculation.

3. Further field experimental test with higher speed and debit of water flow is necessary to get generator performance on loading condition.

\section{AUTHORS' CONTRIBUTIONS}

Thank you to Rusmana for his work particularly on designing the water guide vane and pulley transmission system. Also thank you to Krisna and Erwin Yusuf for conducting and supervising field experimental tests and providing data for analysis. 


\section{ACKNOWLEDGMENTS}

This research was funded and supported by Pusat Penelitian dan Pengabdian Kepada Masyarakat (P3M), Politeknik Negeri Bandung.

\section{REFERENCES}

[1]. B.L. Theraja, A. K. Theraja, A Textbook of Electrical Technology in SI Units Volume II AC and DC Machines, S. Chand Publisher, 2013

[2]. Kumar, A., Tschei, A. Ahenkorah, R. Caceves, J. M. Devernay, M. Freitas, D. Hall, A. Killingtveiet, Z. Liu. (2011). Hydropower, in IPCC Special Report in Renewable Energy Sources and Climate Change. Cambridge University Press, UK and USA.

[3]. J. Zimny, P. Michalak, S. Bielik, K. Szczotka. (2013). Directions in Development of Hydropower in the World, in Europe and Poland in the Period 1995-2011, ELSEVIER. Renewable and Sustainable Energy Review. 21: 117-130.

[4]. A. Date, A. Akbarzadeh. (2009). Design and Cost Analysis of Low Head Simple Reaction Hydro Turbine for Remote Area Power Supply, ELSEVIER. Renewable Energy. 34: 409-415.

[5]. J. F. Gieras, R. J. Wang and Maarten J. Kamper 2008 Axial Flux Permanent Magnet Brushless Machines vol 2 (Springer).

[6]. D. Ahmed, A. Ahmad. (2013). An Optimal Design of Coreless Direct-drive Axial Flux Permanent Magnet Generator for Wind Turbine, 6th Vacuum and Surface Sciences Conference of Asia and Australia (VASSCAA-6), Journal of Physics: Conference Series 439 (2013) 012039, IOP Publishing, 2013, doi:10.1088/17426596/439/1/012039.

[7]. D. W. Chung, Y. M. You, Design and Performance Analysis of Coreless Axial-Flux PermanentMagnet Generator for Small Wind Turbines, Journal of Magnetics 19(3), 273-281 (2014), http://dx.doi.org/10.4283/JMAG.2014.19.3.273.
[8]. G. Messinis, K. Latoufis, N. Hatziargyriou, Design Aspects of Coreless Axial Flux Permanent Magnet Generators for Low-Cost Small Wind Turbine Applications, Scientific Proceedings of the EWEA Annual Conference and Exhibition, Barcelona, Spain, March 2014.

[9]. D. A. Howey, Axial Flux Permanent Magnet Generators for Pico-Hydropower, EWB-UK Research Conference, The Royal Academy of Engineering, February 20, 2009.

[10]. B. Hongpeechar, W. Krueasuk, A. Poungchingngam, P. Bhasaputra, Feasibility Study of Micro Hydro Power Plant for Rural Electrification in Thailand by Using Axial Flux Permanent Magnet, 2011 International Conference \& Utility Exhibition on Power and Energy Systems: Issues and Prospects for Asia (ICUE) DOI: 10.1109/ICUEPES.2011.6497732.

[11]. I M. W. Kastawan, E.Yusuf, M. A. Dzulfiqar, H. Setiadi. (2021). Modification of AC Single Phase Induction Motor to Low-Speed AC Single Phase Permanent Magnet Generator, 2nd International Seminar of Science and Applied Technology (ISSAT 2021), Bandung, Indonesia, October 2021.

[12]. I M. W. Kastawan, Rusmana. (2018). Design and Construction of Axial Flux Permanent Magnet (AFPM) Generator for Harnessing Energy of A Low Elevation River, Asia Future Conference (AFC 2018), Korea, August 2018.

[13]. A. T. Nugroho. In Bahasa (2020). Three-phase Induction Motor Operated as Generator with Steady State and Dynamic Loads.

[14]. S. Wahyu, A. Multi. In Bahasa (2018). 4 kW ThreePhase Induction Motor as Generator with Variation of Capacitor.

[15]. Bruce R. Munson, Donald F. Young, Theodore H. Okiishi. In Bahasa by: Dr. Ir. Harinaldi, Ir. Budiarso, M.Eng. (2005), Fundamentals of Fluid Mechanics Fourth Edition, Jakarta: Erlangga. 